\title{
United by Faith, Divided by Language: the Orthodox in Jerusalem
}

\author{
Merav Mack
}

\section{Introduction}

The Orthodox Church of Jerusalem, known also as the Greek Orthodox or Rum Orthodox Church, is home to a number of ethnic communities speaking different languages, including Greek, Arabic, Russian, Georgian, Romanian and Serbian, and more recently Hebrew as well. ${ }^{1}$ This chapter focuses on the grassroots of the two main communities, the Greek-speaking Hellenic community and the Arabic-speaking Palestinian one, in the first decades of the twentieth century.

The first half of the twentieth century was a period of growing tension between the leaders of the Arab community and the senior Greek clergy, i.e., members of the Brotherhood of the Holy Sepulchre and the Synod of the Church; the scope and depth of this tension is well analysed by Konstantinos Papastathis in his contribution to this book. In this chapter, however, I would like to shift the attention from the leadership to the members of the community and ask: how does a community function when united by religion but divided by language? In other words, I question the relationship between the Greeks and the Arabs at the community level, with an emphasis on the role of the language barrier between them. The focus is on the axis of religion and language and examining the Greek community against migration theories and the studies of language shift and language loyalty, and I concentrate on three expressions of the language divide: the choice of churches, liturgical preferences, and naming patterns.

My sources include archival material that I found in 2014 when I took part in an ERC-funded research project "Open Jerusalem." I worked with a team of scholars and collected baptismal records and marriage certificates from two

1 The ethnic composition of this denomination has been going through major changes in recent years, mainly due to Russian influx in Israel. There are also Hebrew-speaking Christian communities in Israel, in the Latin Church and the Ethiopian Orthodox Tewahedo Church. 
local Orthodox archives, some in Greek and some in Arabic. ${ }^{2}$ The first analysis of this material was published under the title "Matrimony and Baptism: Changing Landscapes in Greek (Rum) Orthodox Jerusalem (1900-1940)" (BJMES, 2017$)$, which I authored together with Angelos Dalachanis and Vincent Lemire. ${ }^{3}$ I have expanded the sources of this chapter with material from the Greek Club in West Jerusalem, and supplemented the archival sources with three autobiographies of Orthodox members of the two communities: Wasif Jawhariyyeh (1897-1972) who grew up in an Arab family, Panayotis Vatikiotis (1928-1997) who had a strong sense of belonging to a Greek community, and the late John Tleel who was also born in 1928 and was descended from a mixed Arab-Greek family. When interviewed, at age ninety, he was still active and assiduously collecting documents regarding the Orthodox community. ${ }^{4}$

\section{The Orthodox Community of Jerusalem}

Much has been written about the Greek-Arab relationship during the Late Ottoman and British Mandate periods, especially regarding the episodes of open conflict between them, or the "rebellion" as some preferred to call the struggle of the Arab lay community against the Brotherhood of the Holy Sepulchre. The Greeks, who were among the first nations around the Mediterranean to gain independence (1832), were proud of their success and were often guilty of over-patronising the local Arab congregation. At the same time, this Arab congregation (much encouraged by the Russians) had begun to question the exclusivity of the Brotherhood of the Holy Sepulchre, which did not allow Arabs into its ranks. Criticism was expressed against the Greek patriarch and what

2 The records are kept in two archives, the Ecclesiastical Court of First Instance (henceforth ECFI) at the Greek Orthodox Patriarchate of Jerusalem, and the archives of the Orthodox Mukhtār, the lay head of the Arabic-speaking Orthodox community in Jerusalem, located inside the complex of the church of St. Jacob (Mār Ya'qūb) (henceforth SJBR). In addition to records of the local Jerusalemite community, the ECFI book contains records of pilgrims who celebrated their confirmation (chrismation) in Jerusalem and its surroundings as well as members of communities in the region. They include 170 matrimonial records (1920-1925) and baptism registers (selected copies in Greek of 513 records from 1875 to 1970, and a chronological register of 1,825 records in Arabic spanning the period of 1928-1944/5).

3 I am grateful to my colleagues: Rana Musa transcribed 1,825 baptismal records from Arabic (SJBR), Dr Gabriel Haritos translated 170 marriage certificates (ECFI), and Dr Falestin Naili reviewed and corrected many of the Arabic records.

4 Wasif Jawhariyyeh, Storyteller of Jerusalem: The Life and Times of WasifJawhariyyeh, 1904-1948 (Northampton MA: Olive Branch, 2013); John N. Tleel, I Am Jerusalem (John N. Tleel, 2007); Panayotis J. Vatikiotis, Among Arabs and Jews, 1936-9o (London: Weidenfeld \& Nicolson, 1991). 
was viewed as Greek control of Palestinian patrimony. ${ }^{5}$ Even the official name of the community or the church was contested. To date, the patriarchate adheres to the title "Greek-Orthodox," whereas the Arab community, distancing itself from the misleading Greekness, prefers "Arab Orthodox" or the historical "Rum Orthodox." The terms are of course synonymous but can be emotionally charged. ${ }^{6}$

But how deeply rooted was the divide between the communities? By turning to baptismal and matrimony records I have found fresh means to study communal relations. Who married whom, what churches did people prefer to attend, in what language did they pray, and what names did they give their children. These particular questions may shed light on the role of Greek language and culture in the lives of the Arabs and the usage of Arabic by the Brotherhood as well the Hellenic community of Jerusalem.

\section{3}

\section{The Religious Landscape of the Orthodox Community}

\subsection{Language of Prayer}

During the British Mandate period sixteen different Orthodox churches in the Old City of Jerusalem had been in use by members of the Orthodox communities. Most of them are churches within small monasteries that date from the middle ages. ${ }^{7}$ They rarely attract visitors from outside the Orthodox

5 Konstantinos Papastathis and Ruth Kark, "Colonialism and Religious Power Politics: The Question of New Regulations within the Orthodox Church of Jerusalem during the British Mandate," Middle Eastern Studies 50,4 (2014): 589-605; Sotiris Roussos, "The Greek Orthodox Patriarchate of Jerusalem: Church-State Relations in the Holy Land between the Palestinian-Israeli Conflict," in Christianity in the Middle East: Studies in Modern History, Theology, and Politics, ed. Anthony O'Mahony (London: Melisende, 2008), 219-31; Laura Robson, "Communalism and Nationalism in the Mandate: The Greek Orthodox Controversy and the National Movement," Journal of Palestine Studies 41,1 (2011): 6-23; Merav Mack, "Orthodox and Communist: A History of a Christian Community in Mandate Palestine and Israel," British Journal of Middle Eastern Studies 42,4 (2015): 384-400; Derek Hopwood, The Russian Presence in Syria and Palestine, 1843-1914; Church and Politics in the Near East (Oxford: Clarendon P., 1969); Daphne Tsimhoni, "The Greek Orthodox Patriarchate of Jerusalem during the Formative Years of the British Mandate in Palestine," Asian and African Studies 12,1 (1978): 77-121.

6 The term "Rum" has its origins in the Byzantine roots of the community when Constantinople was known as the "New Rome." Some of the Arab members of the community prefer to use the prefix "Rum" to distance themselves from the contested denotation of the term "Greek." Both terms are used in this article as well as the more generic reference to the Orthodox community as a whole.

7 Denys Pringle, The Churches of the Crusader Kingdom of Jerusalem: Volume 3, The City of Jerusalem: A Corpus (Cambridge University Press, 2007). 
community and are not mentioned in tourist maps of the city from this period. ${ }^{8}$ Judging by the baptism and matrimony records we can divide them into three types: those that served almost exclusively Greek-speaking monks and Hellenic families; those that served the Arabic community, where liturgy was celebrated exclusively in Arabic; and a few mixed churches where both Greek and Arab families attended the services. ${ }^{9}$

Thus, it was language which mainly divided the churches and parish communities. The most popular churches attended by the Arabic-speaking families were St Jacob's (also called St James, and in Arabic MārYa'qūb) and al-Saidnaiya (formerly known as St. Anne's church). The Hellenic community's most popular church was St Simeon, located at the Qatamon monastery outside the Old City. However, some of the churches were mixed and served both Greek and Arab families. In his autobiography of this period John Tleel mentions St. Basil's as his family's parish church. Tleel's family traces its Jerusalem roots to 1650. John's Arab father and grandfather both married Greek wives from other parts of the Ottoman Empire. The mothers spoke Greek to their children and at the patriarchate school John was also trained in reading and writing Greek. At St. Basil's the Tleels were joined by other mixed families: "We were not the only regulars, many other families came too, all local Jerusalemites, Arabs as well as Greeks. The Sic-Siks and the Hananias were in charge of singing in both Arabic and Greek.... Among the Greek families were the Spathopoulos and the Papadopoulos and Michel Emmanuel."10 All four priests who served in this church were Greek, and according to Tleel the liturgy was held solely in Greek.1 The surnames of the community members in each church seem to indicate that mixed congregations were found also in St. George (Mar Jiris), St Euthymios (Mar Eftimos), Charalampos (Mar Karalambos, formerly Mar Chariton), St. Michael (Mar Mikhail), and St. Nicolas (Mar Nicola). ${ }^{12}$

The wedding certificates show cases of cross marriages between the Greek-speaking congregation and the Arabic one. Thus, for example, one of the Kallona family (Greek) married Khamis ${ }^{13}$ (Arab), Vakaris married into the family of Abdallah Issa, ${ }^{14}$ Papa Anastassios and Qamar; Abu 'Īd and

See for example a tourist map produced by a Jerusalem engineer who was also the secular leader of the Greek community. The Greek churches are marked modestly with a small cross and are not included in the list of sites mentioned at the back. S.N. Spyridon, “Jerusalem: Pictorial Plan” (Jerusalem: Goldberg's Press, 1930).

$9 \quad$ See Mack et al. "Matrimony," Fig. 1, 11 and Appendix 1-2, 20-21.

10 Tleel, $47,53-54$.

11 Interview of $11 / 07 / 2014$.

12 Cf. note 8 above.

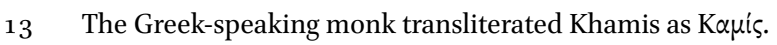

14 ECFI: MC record 147, 20 November 1924. 
Babathobus (Papadopoulos); Georgiathes and Abu Slema (or Abu Salim). ${ }^{15}$ Of course, many of the Arab Palestinian Orthodox families have their roots in Byzantium. One example is the family of George Qamar, the current Arab Orthodox Mukhtār (lay leader) of the community, who belongs to one of the oldest Orthodox families in Jerusalem. According to family tradition their forefather originated from Constantinople in the seventh century where the family name was Kamaris. Over the centuries the name was Arabized to Qamar. ${ }^{16}$

\subsection{Religious Rituals}

The two communities were also divided by religious practices, particularly those related to pilgrimage. It may be trivial to say that local Christians do not have the same concept of pilgrimage as Christians who live outside the boundaries of the Holy Land. One example concerns rituals relating to the Jordan River, an important pilgrimage site and favourite destination for baptism and chrismation in this period. The baptism records contain evidence of dozens of families from various parts of Greece, from Istanbul, and even Tehran and Baku who visited the Jordan River. Four Egypt-born Greeks, from Cairo, Alexandria, Port Said and Suez (Qantara) were baptised in the holy river.

For many Greek pilgrims the journey to the Jordan River was a transformative experience which, as in Islamic practice, changes the status and name of the pilgrim. The word for 'pilgrim' in modern Greek is chatzis ( $\chi \alpha \tau \zeta \dot{\zeta} \zeta)$, which is derived from the Arabic hajj and is also used as a prefix of Greek surnames, such as Hadjandreas.

According to our sources, 46 children from Jerusalem, all descendants of Hellenic families, were baptised in the Jordan River. Figure 10.1 is a blurred, unnumbered photograph from the collection of the Greek Club, probably from the 1920 or or 1930s, showing a priest with a couple holding a baby in a boat with seven other men.

The Arabic-speaking congregation did not follow the practice of baptism and chrismation at the Jordan River. When I asked John Tleel why the Arab Orthodox do not follow this tradition he said:

we are not like the Greek hadji; they must go to the Jordan River. We were

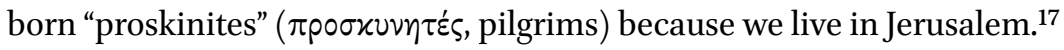

\footnotetext{
15 In Arabic Qamar and Bābā Anāstī, SJ BR record 411 (31 August 1933); Abū 'Ĩd and Bābādūbus, record 1526 (17 May 1943); Abū Salīma and Jiyūrjiyādhus, record 1732 (27 November 1944).

16 Interview, 12 April 2016.

17 Interview 18 July 2014.
} 


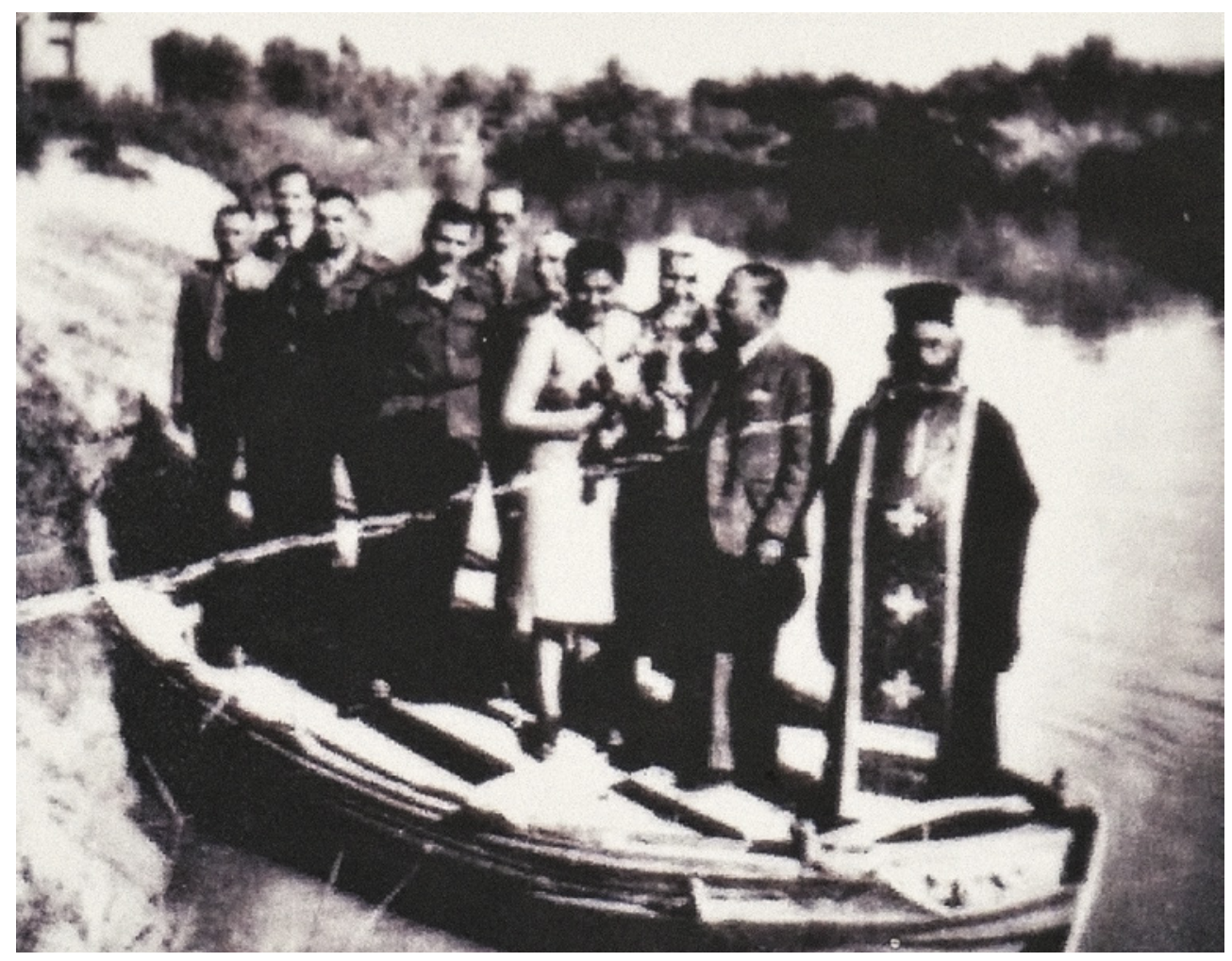

FIGURE 10.1 The Greek Club Collection: at the Jordan River

The attitude to the holy sites was just one example of the divides between the two sub-communities. Other differences often included wealth, education, professions (possibly class) and locations of residence in the city, all of which contributed to their separation from each other and also affected the language divide. ${ }^{18}$

\section{$4 \quad$ Language Divide}

Wasif Jawhariyyeh, known also as "the oud player" and "the storyteller of Jerusalem" (after his autobiography which was published under this title by Salim Tamari) was born in Jerusalem in 1904. His childhood home Dar Jawhariyyeh was in the neighbourhood of al-Sacdiyya, at a hilltop between

18 Mack et al., see note 1 [above]. 
Damascus Gate and Herod's Gate. Christian families had lived in this part of the Old City in the early twentieth century, but they were exclusively Arab. Wasif's father was a lawyer and an autodidact who "taught himself Arabic, Turkish and then Greek." ${ }^{19}$ His prestigious profession and abilities secured him a high position at the community. In 1884 he was appointed Mukhtār, working closely with the heads of the municipality and the municipal council, and had especially close relations with al-Nashashibi and al-Husseini families. Patriarch Damianos appointed him a member of the ecclesiastical court. ${ }^{20}$

Wasif himself, however, did not receive any Greek education. Instead, he was first sent to the Lutheran Dabbagha School near the Church of the Redeemer in the Old City, were he learnt Arabic and "some German." "The school was mainly attended by Arab Greek Orthodox pupils" explains Jawhariyyeh, so it was a remarkable choice considering that the Orthodox school of St. Dimitri was only a few streets away. As Konstantinos Papastathis shows, it was not unusual for the Arab Orthodox families to prefer other denominational schools. Wasif was later transferred to Khalil al-Sakakini's modern dustüriyya School (an Arabic national school of no religious affiliation), where he learnt Quranic Arabic, Turkish and French but not Greek. ${ }^{21}$ The school director and famous educator Khalil al-Sakakini was an Arab Orthodox. The decision not to include Greek as one of the languages taught at school was probably pragmatic, but may also reflect Sakakini's personal antagonism against the Greek administration of the patriarchate and the Brotherhood of the Holy Sepulchre. ${ }^{22}$

Nevertheless, in the eyes of Wasif Jawhariyyeh Greek education was superior. In one of his diary entries he compares his childhood education with his wife's, and says: "Victoria was fortunate to receive a superior Greek education and lived a quiet aristocratic life, broadening her knowledge of astronomy and classical Greek."23 In another entry he describes his visit to the patriarch, during which Victoria had to translate the conversation. The memoirs reveal no resentment against the Brotherhood of the Holy Sepulchre or the patriarch. Rather, he writes: "I stood admiring his extraordinary looks, glorious beauty, and lofty stature which he maintained despite his old age."24

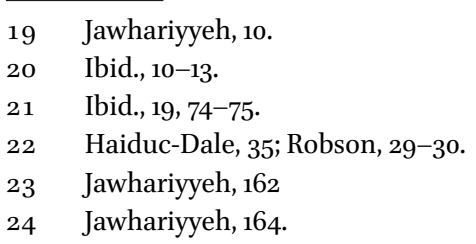


For the children of Greek families in Jerusalem, even after several generations, Greek language and a sense of separate identity were important. In the Arabic baptism register of St. Jacob's church there is a unique column header: "watan al-mu'ammad," which translates as "the homeland of the baptized" and is separate from the column "place of birth." There are 115 cases of children for which this column indicates "Greece," even though 108 of them were born and raised in Jerusalem, and many of them were baptised in their own homes, or in some cases even in their grandparents' houses. They were clearly neither pilgrims nor visitors, but rather second- and even third-generation Jerusalemites. Yet, the community classified them Greek in the Arabic register. The Arab members of the community would have understood and felt connected to this notion of belonging. Cyrus Schayegh shows the importance attributed to the notion of wațan to Arab nationalists in this period. He quotes the Lebanese scholar Butrus al-Bustani: "watan is the house of residence of a man and his (fixed) abode whether he was born in it or not." Al-Bustani elaborates that "in modern times, love of the homeland is [an article] of faith." 25

The Greek notion of national belonging is not unique to those living in Jerusalem or the Holy Land. Greek migrants had long settled throughout the Mediterranean and even beyond, following work and other opportunities, but often kept their sense of belonging. When describing such communities, Greek

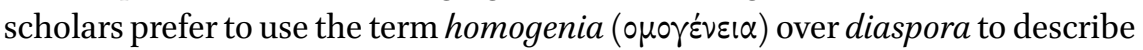
members of ethnic Greek minorities in foreign countries who themselves or their ancestors have never lived on Greek soil. ${ }^{26}$ Still, for Hellenic Christians Jerusalem is not the same as other foreign cities. After all, one of the unique facts about Jerusalem is that Greeks have been present in the city continuously for nearly two thousand years, and that Greek has been one of the city's principal languages.

Language shift plays a central part in theories of migration and acculturation. Scholars refer to a "third generation principle" as a rough indication of the

25 Butrus al-Bustani, Muhit al-Muhit (Beirut: s.n., 1870), 2:2265, translated by Cyrus Schayegh, The Middle East and the Making of the Modern World (Harvard University Press, 2017), 45.

26 Yiorgos Anagnostou, "Where Does 'Diaspora' Belong? The View from Greek American Studies," Journal of Modern Greek Studies 28 (2010), 85. 
period of erosion of pre-migration identities. In a classic, often quoted (and criticized) essay Joshua Fishman wrote:

The erosion of ethnicity and ethnic identity experienced by most (but not all) American ethnic groups takes place in the course of three generations ... ethnic heritage, including the ethnic mother tongue, usually ceases to play any viable role in the life of the third generation.... [The grandchildren] become literally outsiders to their ancestral heritage. ${ }^{27}$

However, the Greek diaspora in Jerusalem in the first half of the twentieth century did not follow these patterns of migration. Having Greek-speaking churches, clergy who continued to come from Greece, schools and clubs helped them keep their communal identity. And so they preserved their national affiliation and maintained a loyalty to their language and ethnicity over the course of three generations and longer. One indication of the growing gap between the communities can be seen by the choice of names. Breaking away from the common religious naming patterns, both communities seem to have preferred given names that were more closely related to their cultures and national identity. In the Appendix to this chapter the more popular female names in the 1930 are listed to demonstrate the differences between the two communities.

\section{Hellenic Jerusalemite Identity}

The story of Hellenic life in Jerusalem in this period is exemplified also by the biography of Panayiotis Vatikiotis. Born in 1928, Panayiotis was a third-generation Greek in Palestine. His grandfather Yannis travelled from the island of Hydra to Acre, where he married a poor Orthodox Nazarene girl named Evmorphia (Jamila), a maid at a local tavern in Acre, a girl he described as "thoroughly Hellenized."28 Panayiotis's father Gerasimos was born in Acre in 1900, worked as a telegrapher and married Panayiotis's mother, a Jerusalem woman born of Greek parents (Emanuel and Zoe Meimarakis). From Jerusalem Panayotis's parents moved to Qantara, following work opportunities at the maritime company of the Suez Canal. There, they founded "a lively community with its own

27 Vladimir C. Nahiri and Joshua A. Fishman, "American Immigrant Groups: Ethnic Identification and the Problem of Generations (1965)," in Theories of Ethnicity: A Classical Reader, ed. Werner Sollors (NYU Press, 1996), 266.

28 Panayiotis J. Vatikiotis, Among Arabs and Jews, 1936-9o (London: Weidenfeld \& Nicolson, 1991), 9. In the wedding certificates in the ECFI records she is mentioned by her Arabic name Zemile, which means Jamilla. Matrimony Records, 128 of 19 August 1928. 
church (St Spyridon) and school ... and generally continued to be as Greek in the diaspora as ever."29 As a child, Vatikiotis had both Jewish and Arab friends, but he was brought up to view himself as different from both.

I was born in Palestine (Jerusalem) and spent the first seventeen years of my life there: my childhood, boyhood and adolescence ... I was surrounded by Arabs and Jews in school, in my neighbourhood, in the streets, on the bathing beaches ... I am, incidentally, neither an Arab nor a Jew.

What is significant perhaps is that a Greek home, a Greek school and the Greek Church made sure that no Greek growing up in the Holy Land - in Palestine - forgot for a moment that he or she was neither Arab nor Jew, but plain Greek. ${ }^{30}$

In later years Panayiotis Vatikiotis became an important scholar, with meaningful views on the same subjects analysed here. He reflects, for example, on the "religious ingrained patriotism" that characterized the Greek community, which was extended through marriage to the local Palestinian population, too. Greek women married local Arabs continued to bring up "Hellenized" children. ${ }^{31}$ Many years after he left Palestine-Israel and moved to live in Britain, Vatikiotis criticized the nationalistic sentiment of his childhood. In his memoirs he blames the community that "turned us into fanatic Greeks encumbered by all the ignorant chauvinism of nationalism."32

Figure 10.2 is a photograph from the collection of the Greek Club, showing some of the children of the community of similar age as Panayotis Vatikiotis, with Patriarch Damianos (1897-1931) standing at the top of the patriarch's residence's staircase. It was taken in Qatamon, near St. Simeon's Church, probably in the late 1920s. ${ }^{33}$

29 Vatikiotis, Among Arabs and Jews, 19.

$30 \quad$ Ibid., 1.

31 Ibid., 8.

32 Ibid., 13, 28.

33 These children were probably a little bit older than Panayotis Vatikiotis, who was born in 1928. The children in this photograph could be the same ones listed in the baptismal records, although I could not find anybody who could still identify them by name. 


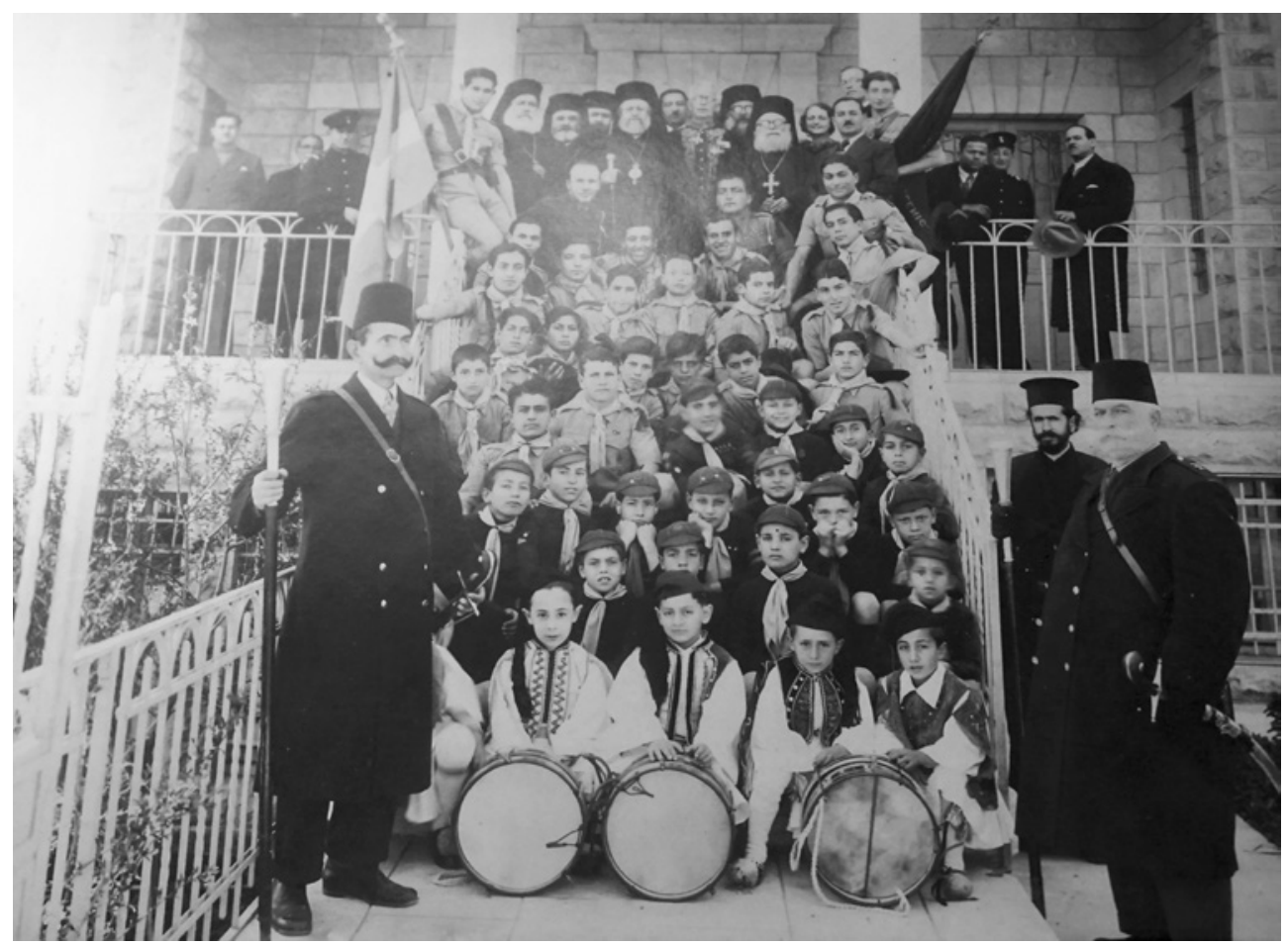

FIGURE 10.2 Greek boys in scout, cub and band uniforms with Patriarch Damianos at his Qatamon residence

\section{Conclusions: between Religion and Language, between Greek} and Arabic

Sixty years after the end of the British Mandate, the small Greek Club today stands in the heart of West Jerusalem, but its Greek members amount to just a handful of families. The vibrant Hellenic people had moved away, some to Greece and some, keeping with the tradition of travel, had moved on, some as far away as Australia. A few families remain, headed in 2018 by Anastas Damianos, who continues to keep the club active. The club continues to host multilingual events where Greek remains a dominant language alongside English, Hebrew and Arabic.

The issues of language, religious practicalities and ethnicity remain sensitive in Jerusalem even today. Therefore, scholars sometimes fall into the trap of judging the early twentieth-century community according to the situation 
today. This is a mistake. Many of the senior members of the synod, including the patriarch, speak Arabic fluently today, and the patriarchate issues weekly sermons in Arabic. None of that existed in the first half of the twentieth century. At that time Greek served as an alternative to Arabic, often suppressing it. Greek families kept separate from the Arab faithful and remained loyal to their language and ethnicity. And so, despite their shared faith, the children of the Arab and Greek communities grew up separately.

\section{Appendix: Comparison between the Names Given to Orthodox Greek and Arab Girls in Jerusalem in the 1930 s and 1940 s}

Popular female names in Jerusalem's Greek community in the 1930 s and 1940 s
Popular female names in Jerusalem's

Arab community in the 1930 s

\begin{tabular}{|c|c|}
\hline Anna (17\%) & Laylā (15\%) \\
\hline Eleni $(14 \%)$ & Mary (Mārī) (14\%) \\
\hline Anastasia $(12 \%)$ & Nadia (Nādiya) (10\%) \\
\hline Maria $(12 \%)$ & Georgette (Jīrjīt) (9\%) \\
\hline Hariklia $(10 \%)$ & Violet (Fīyūlìt) (7\%) \\
\hline Evangelia (7\%) & ‘Ā'ida (6\%) \\
\hline Fotini $(7 \%)$ & Jamīla (6\%) \\
\hline $\operatorname{Irini}(7 \%)$ & Su'ād (6\%) \\
\hline Ourania (7\%) & Nāhida (5\%) \\
\hline Stavroula $(7 \%)$ & $\operatorname{Il} \bar{n} \overline{1}(4 \%)$ \\
\hline
\end{tabular}

\section{Bibliography}

Campos, Michelle Ursula. Ottoman Brothers: Muslims, Christians, and Jews in Early Twentieth-Century Palestine. Stanford: Stanford University Press, 2010.

Haiduc-Dale, Noah. Arab Christians in British Mandate Palestine: Communalism and Nationalism, 1917-1948. Edinburgh University Press, 2013.

Hopwood, Derek. The Russian Presence in Syria and Palestine, 1843-1914; Church and Politics in the Near East. Oxford: Clarendon P., 1969.

Jawhariyyeh, Wasif. Storyteller of Jerusalem: The Life and Times of Wasif Jawhariyyeh, 1904-1948. Northampton MA: Olive Branch, 2013. 
Kark, Ruth, and Michal Oren-Nordheim. Jerusalem and Its Environs: Quarters, Neighborhoods, Villages, 1800-1948. Wayne State University Press, 2001.

Katz, Itamar, and Ruth Kark. "The Church and Landed Property: The Greek Orthodox Patriarchate of Jerusalem." Middle Eastern Studies 43, 3 (2007): 383-408. doi:10.1080/00263200701245969.

Katz, Itamar, and Ruth Kark. "The Greek Orthodox Patriarchate of Jerusalem and Its Congregation: Dissent over Real Estate." International Journal of Middle East Studies 37, 4 (2005): 509-34.

Kildani, Hanna. Modern Christianity in the Holy Land. Bloomington, IN: Author House, 2010.

Mack, Merav. "Christian Palestinian Communities in Israel: Tensions between Laity, Clergy, and State." In Sacred Space in Israel and Palestine: Religion and Politics, edited by Marshall J. Breger, Yitzhak Reiter, and Leonard Hammer, 284-309. Routledge, 2012.

Mack, Merav. "Orthodox and Communist: A History of a Christian Community in Mandate Palestine and Israel." British Journal of Middle Eastern Studies 42,4 (2015): 384-400.

Mack, Merav, Angelos Dalachanis, and Vincent Lemire. "Matrimony and Baptism: Changing Landscapes in Greek (Rum) Orthodox Jerusalem (1900-1940)." British Journal of Middle Eastern Studies 45,3 (2018): 443-463; online Jan. 2017: 1-21. doi:10.1 080/13530194.2016.1273093.

O'Mahony, Anthony. "The Christian Communities of Jerusalem and the Holy Land: A Historical and Political Survey." In The Christian Communities in Jerusalem, edited by Anthony O'Mahony, 1-37. Cardiff: University of Wales Press, 2003.

Papastathis, Konstantinos, and Ruth Kark. "Colonialism and Religious Power Politics: The Question of New Regulations within the Orthodox Church of Jerusalem during the British Mandate." Middle Eastern Studies 5o (2014):589-605.

Robson, Laura. Colonialism and Christianity in Mandate Palestine. Austin: University of Texas Press, 2011.

Roussos, Sotiris. "The Greek Orthodox Patriarchate and Community of Jerusalem: Church, State and Communal Identity." In The Christian Communities in Jerusalem, edited by Anthony O'Mahony, 38-56. Cardiff: University of Wales Press, 2003.

Roussos, Sotiris. "The Greek Orthodox Patriarchate of Jerusalem: Church-State Relations in the Holy Land between the Palestinian-Israeli Conflict." In Christianity in the Middle East: Studies in Modern History, Theology, and Politics, edited by Anthony O'Mahony, 219-31. London: Melisende, 2008.

Spyridon. S.N. “Jerusalem: Pictorial Plan.” Jerusalem: Goldberg's Press, 1930.

Tamari, Salim. “Jerusalem's Ottoman Modernity: The Times and Lives of Wasif Jawhariyyeh." Jerusalem Quarterly 9 (2000): 5-27.

Tleel, John N. I Am Jerusalem. John N. Tleel, 2007. 
Tsimhoni, Daphne. "Continuity and Change in Communal Autonomy: The Christian Communal Organizations in Jerusalem 1948-80." Middle Eastern Studies 22,3 (1986): $398-417$.

Tsimhoni, Daphne. "The Greek Orthodox Patriarchate of Jerusalem During the Formative Years of the British Mandate in Palestine." Asian and African Studies 12,1 (1978): 77-121.

Tsimhoni, Daphne. "The Status of the Arab Christians under the British Mandate in Palestine." Middle Eastern Studies 20,4 (1984): 166-92.

Vatikiotis, Panayotis J. Among Arabs and Jews, 1936-9o. London: Weidenfeld \& Nicolson, 1991. 